\title{
Young Children's Human Rights: a sociological analysis
}

Priscilla Alderson,

\begin{abstract}
Children tend to be missing from the literature on human rights. Sociology can help to fill the gap by providing evidence about the importance and benefits of recognising children's human rights, the dangers of not doing so, and joint rights-promoting work by adults and children. However, sociology has paid relatively little attention to human rights, and to the related topics of the Holocaust, human nature, real bodies, universal principles and moral imperatives. This paper examines splits in sociology around a central absence, which could partly explain these omissions. Then it considers how inter-disciplinary approaches and critical realism can help to theorise and validate "the inherent dignity and...the equal and inalienable rights of all members of the human family". The youngest children's rights illuminate meanings in all human rights, which depend less on the rational person approach than on recognising human nature, vulnerability and solidarity interacting with social structures.
\end{abstract}

\section{Key words}

Absence, babies, children's rights, critical realism, embodied rights, Holocaust, human nature, universal principles 


\section{Introduction}

This discussion paper reviews how, and possibly why, children are often missing from the mainly adult-centred, academic and popular literature on human rights. Writers imply that human rights belong mainly to adults and are separate from children's rights. Sociology can help to fill these gaps by providing evidence about the importance and benefits of recognising children as full human beings with human rights, the dangers of not doing so, and ways in which adults and children work together to promote everyone's human rights. However, mainstream sociology has tended to be ambivalent and to pay relatively little attention to children, to human rights generally, and to topics which are arguably closely related to rights: the Holocaust, real bodies, human nature, universal principles and moral imperatives. This paper examines splits in sociological theories and methods around a central absence, which could help to explain these omissions. Then I will consider how interdisciplinary approaches and critical realism can help to theorise "recognition of the inherent dignity and of the equal and inalienable rights of all members of the human family [as] the foundation of freedom, justice and peace in the world" (United Nations, 1948). The youngest children's rights illustrate a reality in human rights that is not founded on the rational person, but on recognition of human nature, vulnerability and solidarity interacting with policy structures.

The sociologist Michael Freeman (2011) considers that one task of social science is to bring human rights supporters and lawyers back to reality, by connecting abstract notions of rights into their social contexts, structures and meanings, where normative philosophy, law and social science meet. Woodiwiss (2005) and Hynes et al. (2011) also contend that sociology can analyse the complex meanings and relevance of human rights in numerous social processes and relationships. Freeman (2011:118) believes that divisions between social science and philosophy, which attempt to "purify" the disciplines, have advantages but also costs. The problems posed "can be met only by intellectual activity that crosses the boundaries we have set up". This paper considers how we can understand more about the reality of human rights and about sociology by crossing traditional academic boundaries, and by transcending debilitating splits, contradictions and dichotomies (which reduce things into two opposing sides: human becomes adult/child).

Children might seem to disappear from much of this paper. However, this is because I want to show that supposedly "adult" matters of economics and politics affect everyone of all ages, and their rights. Feminists showed that women were both invisible in pre-1970s male-centred sociology, but were also inevitably central to it. Feminists also assert that society can only properly be understood by taking account of women as well as men. Similarly, this paper argues that children and young people are (still too often) invisible in adult-centric sociology and human rights literature. Yet in being over one third of humanity, they are central. Accounts that omit them are therefore skewed and partial, and relate to the vital theme in critical realism of absence (see below). Instead of repeatedly writing "and also children", I take "human" and "society" to mean everyone of all ages. 
The lawyer Michael Freeman (2012, and see 2007) contends in his edited interdisciplinary book on childhood studies and the law: "All areas of law [and therefore of rights] impact upon children, and have concepts of childhood". But Freeman shows how traditional concepts of children and childhood are often assumed, and are not explicitly recognised or questioned. Real children are then absent in a sense of being submerged below the level of conscious discourse, decisions and policy making. Supreme Court judge Brenda Hale (2011) recounted how children and their rights are repeatedly overlooked in the courts. She cited examples of lawyers using children's Article 12 rights to express their views merely to reassure and partially inform children, but not to listen to them or learn from them. Parents of young children frequently receive prison sentences with no thought, Hale considers, of the children, despite the 1989 Children Act, and Convention on the Rights of the Child, UNCRC (UN, 1989) Article 3:

"In all actions concerning children, whether taken by public or private social welfare institutions, courts of law, administrative authorities or legislative bodies, the best interests of the child shall be a primary consideration."

Children are too often absent, in terms of being present and centrally relevant but invisible, unheard, excluded, ignored or unconsidered, not only in the law courts, but also in the whole criminal justice system when parents' prison sentences could impose on their children worse deprivation, emotional suffering and stigma than the parents might endure in prison. Since almost everything in society concerns children, "all matters affecting the child" (UNCRC, 1989: Article 12) applies to almost everything too.

If children are specifically included only sometimes, it is inadvertently implied that they are absent at all other times. This a major problem created by the UNCRC and its supposed creation of children's rights, which diverts attention from "everyone's" rights in older Conventions. This can perpetuate the default assumption that only adults count, unless children happen to be mentioned. One purpose of my paper, however, is to promote the default assumption to include children, and then to justify any specific exclusion. This paper is neither about rights exclusive to young children, nor much about the UNCRC, except in the many rights the UNCRC shares with other conventions (such as UN, 1948; EC, 1950). The paper is about how seeing young children aged 0-8 years as rights holders might increase our understanding of the civil and economic rights that are shared by every human being. This theoretical paper has developed from my related, more practical books (Alderson, 2008; Alderson and Morrow, 2011).

Instead of reporting an empirical research project, this paper reviews problems in the current sociology of human rights, with suggested ways to analyse and resolve them. It will draw on the fairly new philosophy of critical realism - CR (Bhaskar 1998, 2008, 2010, 2011). Central to this paper and to CR is the difference between ontology (here meaning being, real existence and functioning) and epistemology (here meaning knowing, thinking, perceiving, understanding, describing, explaining). 
CR contends that most philosophy and sociology collapses being into knowing, things into thoughts and, for example, real living children into concepts, beliefs and discourses about childhood. Although CR texts are dense, after nearly 30 years as a sociologist I find them immensely useful in explaining and resolving deep problems in social research, and I aim to explain ideas from CR as clearly as possible (Alderson, in press).

An ontology of human morality and human rights (their existence, nature and function) has a stronger basis if it connects with an ontology of human nature and can show how: 1) the ends of the morality and rights are conducive to human good and flourishing (interdependent with other species, nature and the planet); 2) the means through which we desire and aim to achieve this good are not simply arbitrary or synthetic, but are authentically part of human nature, in their origins, processes and effects.

However, in order to define their discipline, sociologists have set knowing over being, culture over nature. They have tended to select narrow concepts of the social, and to research contingent culture and empirical data, separated from universal nature, philosophical inquiry and underlying, invisible causes (Bhaskar 1998). There are also deep divisions and contradictions between positivist and interpretive, qualitative and quantitative, micro and macro approaches to childhood research.

One example of splits and omissions is that it was not until the sixtieth annual British Sociological Association (BSA) conference in 2011 that the very first stream on human rights was convened. Yet readers hardly need to be reminded that human rights are of immense, long-standing and international social concern. The BSA was set up in 1951, shortly after the catalyst for the recognition of international human rights (United Nations, 1948; European Council, 1950), and also for international research ethics (Nuremberg Code, 1947). The catalyst was the Nuremberg Trials held after the Holocaust. A related omission in sociology is inattention to research ethics and participants' rights. In contrast to decades of ethics activity in healthcare research stemming from Nuremberg (many conferences and courses, books and journals, reports and agreed standards, formal review committees and the new discipline of bioethics), social researchers only began to accept routine, formal ethics review of their work during this century (ESRC, 2005).

In order to consider possible origins of, and justifications for, human rights that are rooted in human nature, this paper is relevant to the social and natural sciences and humanities concerned with human life. I will ask: Can moral values and rights be universal or only contingent and local? When does something seemingly as enduring as the individual human person and rights holder begin? And how might critical realism help to increase understanding of young children's human rights?

The following sections review the history of sociology in ways that I hope practical readers will find useful. Sociology analyses and informs everyday public opinions and values, and examines unseen, underlying beliefs and processes, which may be aiding or blocking social progress. Success in slow reform, such as on women's and children's rights, involves understanding these deeper resistances and enablers. I will first consider four selected major strands in sociology that have influenced public 
values and policies. Then I will review contradictions and dichotomies among the four strands, and critiques about them. Later sections will outline a few selected themes from critical realism to show how these can illuminate human rights and help to resolve contradictions. The $\mathrm{CR}$ themes include absence, ontology and epistemology, depth realism, closed and open systems, structure and agency, and four planar social being.

\section{Four major strands in sociology}

Twentieth century sociology developed through international collaboration. Leading American sociologists studied and worked at times in Germany. Contact increased during the 1930s, with refugees from continental Europe fleeing to the USA and UK. From Marx and Durkheim onwards most prominent founding sociologists were Jewish, and sociology could be said to owe its existence to them. The Holocaust directly affected many sociologists, when they sought asylum and when their relatives and/or friends perished in the concentration camps. Yet unlike historians, sociologists have maintained almost complete silence about the Holocaust (from the Greek "whole" and "burnt"). The sociologist Zygmunt Bauman (2003:175-6) considered their silence on one of the extreme social events of the twentieth century, after his wife spent two years writing about her time in a concentration camp. Bauman believed that the general avoidance or denial were partly defences against the pain and horror of instinctive moral revulsion. Sociologists' tactics have included: ignoring atrocities and the physical torment of the body; explaining them away as unique and irrelevant to a theory of morality; regarding them as exceptions that prove the rule and mark the boundaries of morality; or retreating into moral relativism. Bauman identifies all these responses in sociology from the 1940s.

Sociologists' general silence and defensive anxieties may have been accentuated into this century by the further wars, atrocities and genocides. From a wide range of sociological groups or schools, I have selected four broad strands developed around the 1940s and 1950s. These illustrate different tacit or overt reactions to the Holocaust, and by association to the violation and defence of human rights. The reactions could have contributed to deepening the gaps and splits in sociology, along with many older divisions (Gouldner, 1971; Bhaskar, 1998). Before human rights can be accepted generally in mainstream sociology, it may be necessary to rethink widespread assumptions propagated by these disparate strands, which this section will briefly review.

\section{Structural functionalism}

Talcott Parsons and structural functionalists, through a kind of remote optimism that denied the dangers of an over-powerful state, seem determined to show just how civilised society can be. They saw society as a great organism or system, functioning for the good of all, inexorably preventing social breakdown, and defending "American values" against communism and fascism. They shared Durkheim's and Weber's view 
that, to qualify as science, sociology must (at least appear to) be value-free, and so they emphasised practical utility rather than moral principles. Weber's respectful Verstehen (understanding) of different cultures and moralities (implicitly countering the idea of one universal morality) was also deeply influential (Gouldner, 1971; Bhaskar, 1998; Bauman, 2003). Parsons (1951) emphasised the social, partly by demoting the natural; for example, physical bodily disease and suffering transferred into the social, compliant sick role. Parsons shared Durkheim's (1956) concepts of morality emerging within each society in a God-like collective conscience, which rescues individuals from blind, unthinking, physical forces and natural animal passions. This morality serves to strengthen orderly cohesion, and is sustained through socialising and educating each new generation into compliance, with correction of deviance. Human rights are hardly necessary if governments are correct and benign, and functionalists would regard the birth of human rights through protest as deviance that requires correction not respect. Sociologists' confidence increased in promoting science, technology and wealth creation through efficient and inevitably proliferating bureaucracy. Weber (1970:214) described bureaucracy before he died in 1920, and inadvertently forecast the Holocaust:

"Precision, speed... knowledge of the files, continuity, discretion, unity, strict subordination, reduction of friction and...costs, the 'objective' discharge of business according to calculable rules and 'without regard for persons' - or for personal initiative."

\section{Interpretivism}

Claiming similar value-freedom, a second strand could be seen as containing Holocaust-related anxiety by "bracketing off" macro concerns of politics, justice, power and economics as well as the physical world (and real bodies and suffering). This interpretive group positioned the social within detailed micro encounters and negotiated meaning. They saw reality (being) not as real but as a form of consciousness (knowing), in such sociological approaches as: phenomenology (individual meaning making); social constructionism (Alfred Schütz, also Peter Berger and Thomas Luckmann); ethnomethodology (Harold Garfinkel); and discourse analysis. At Chicago, research by symbolic interactionists (Herbert Blumer, Howard Becker, Erving Goffman, Louis Wirth and Eliot Freidson, with sociologist/economist Gary Becker who worked on human capital) and grounded theorists (Barney Glaser and Anselm Strauss) mainly avoided reference to the Holocaust or to human rights, despite their relevance to such research topics as total institutions or stages of awareness of dying. Concepts of the distinct moral self as a rights holder became fragmented into a series of presentations and performances by "merchants of morality" (Goffman, 1969:222). Berger and Kellner (1981:141-2) firmly divorce sociology from morality, saying that the futile search for seductive ideologies, such as Marxism, and religions that offer existential hope and moral guidance must, with all fanaticism, be avoided. Childhood studies is mainly influenced by this strand, when sociologists, geographers and anthropologists study a range of very diverse 
childhoods, and show how these are socially constructed and not biologically determined. Researchers thereby challenge psycho-medical theories of universal child development (James and Prout, 1997). This can be emancipatory when accounts of young children in the poorer Majority world who run small businesses (Invernizzi, 2008), or work as soldiers (Brett and Specht, 2004) refute Western assumptions about 8 year olds' inevitable rather helpless dependence.

Later in this interpretive tradition, Bryan Turner (2008) made a vital sociological defence of human rights, which he connected to religion, to evil, and to the animal vulnerability and prolonged childhood of human beings. We need rights because we are easily harmed, and not fully protected by our social institutions; we share a core value of "collective compassion" and responsibility to relieve each others' misery. However, Turner tended to split the social and thinking about bodies, from the natural and humans existing in and as bodies. He stated that sociologists are mainly concerned with the former, with "cultural decoding of the body as a system of meaning" and also "the phenomenological study of embodiment" and practices (Turner, 2008:15).

\section{Critical theory}

A very different strand was more critical of oppression and the Holocaust. They included in the USA Everett Hughes, who wrote a rare critique of Nazism, C Wright Mills and Alvin Gouldner. There was also the Frankfurt School, temporary exiles in New York during World War II. Despite being critical theorists, some of them tended to emphasise subjective psychology and to avoid history and political economy (Bottomore, 2002). From around 1980 to 2007, this third group's critical Marxist approach, the one most likely one to address the Holocaust, lost influence, although today Marxism is becoming more popular, as a means to analyse today's problems, which partly stem from the next and fourth group's work.

\section{Econometrics}

Economics and politics were the fourth strand's main concern. Their reaction to the Holocaust was to plan social reform that was supposed to be the antithesis of Nazism and communism. Although mainly economists and philosophers, they were crucial to the history of sociology with its roots, evinced by Marx, Weber and Parsons, in economics. The Chicago sociologists (strand 2) shared their building (and some researchers such as Gary Becker) with the economists. The entrance was inscribed "science is measurement". Economist Milton Friedman worked there, with Frederick von Hayek and Karl Popper, refugees from Vienna and based at the London School of Economics. Their Mont Pelerin Society has propagated neoliberal policies throughout the world since the 1940s (Klein, 2007; Mirowski and Plehwe, 2009).

Their revulsion of "serfdom" under Stalinist and Nazi atrocities fed their aspirations towards free, unregulated, "open" societies and markets. Neoliberal policies have overseen the splitting away and transfer of government funding for sociological research into social policy, economics, statistical and business departments, and 
commercial agencies. Concern with social relations, the arena for human rights, has been colonised and overtaken by today's most influential and well funded agendas, such as huge surveys and evaluations about cost-effectiveness, evidence base, and happiness metrics (Layard, 2006).

Neoliberals' passion for a highly qualified form of freedom (of markets rather than of people or rights) has shaped the methods as well as the remit and topics in social research. Popper (1945/1965) claimed that modern science formed during the $17^{\text {th }}$ century Enlightenment was "perhaps the greatest of all moral and spiritual revolutions of history" although it "has created powers of appalling destructiveness; but they may yet be conquered" when people "free themselves and their minds from the tutelage of authority and prejudice" and "build up an open society". They do so through freely subjecting any idea or tradition to rigorous deductive research and falsification, to see whether it can "measure up to their standards of freedom, of humaneness, and of rational criticism". Then they can "share the burden of responsibility for avoidable suffering, and...work for its avoidance". These high ideals have informed, for example, the international Cochrane Collaboration (Chalmers, 2005), which tests the cost-benefit evidence of interventions in many health, social and education services.

Splits between these four strands are epitomised in the example of Alfred Schütz. A fellow economics student with Hayek in Vienna, he escaped to New York in the 1930s. He re-established his career as a banker and attended Mont Pelerin meetings (strand 4), while he also developed sociological phenomenology (strand 2), largely divorced from economic, political, material and moral considerations. The four strands contradict one another's theories, aims and methods: whether to measure and assume everyday reality, or to try to understand while doubting that anything is real or universal.

\section{Critiques of the four strands}

Criticisms of the strands' continuing influences, particularly relating to social research about human rights and children, will now be reviewed. Some of the gaps between these four traditions have narrowed, such as in the present most active area of research about children (funded by Government departments and research councils, the International Monetary Fund and similar agencies). Commissioned research synthesises functionalist maintenance of social order (strand 1) with positivist surveys (strand 4), stored in vast databanks, of children's cost-related needs and performance and the services that support and control them. Children are implicitly burdens, or investments and future funders of older generations' pensions and debts, rather than unique persons and rights holders (for example, Dex and Joshi, 2005). The birth cohort to begin in 2012 at University College London has initial funding of $£ 33$ million. 
Gouldner and Bauman mistrusted the enforced consensus of functionalism, considering that intellectual and moral knowledge develop through difference and conflict, through informal being-with-the other and, like Socrates, stepping out of assigned roles. Gouldner (1971) analysed how functionalism in the well-ordered social organism is inexorably utilitarian when it values each part according to its functioning or utility, including morality that is designed to promote order and efficiency but not justice. Bauman and others, such as Hannah Arendt, conclude that the Holocaust was not a failure of modern civilisation, but its product. They invert Weber's and Parson's smooth bureaucratic rules, contending that ordinary, good people can commit evil when they obey experts' orders, transfer responsibility up the hierarchy, and fail to regard victims as persons. For Bauman (2003), the perpetrators, bystanders and the relatively rare protestors during the Holocaust offer the ultimate lesson about the extent of human good and evil. He identifies morality not with obedience to Durkheim's enforced norms, but with the exceptional courage to protest, and to follow individual conscience, particularly in unjust and murderous societies. This courage sets principles of solidarity and altruism above personal survival, and is expressed by the Arab protestors in 2011 who said, "We will die for our freedom", implying their willingness to die for other people's freedom. They dispel myths that only Westerners value universal freedom and solidarity rights.

As mentioned earlier, Durkheim (1956) viewed each society as the source of all its own morality; he assessed morality for its efficient maintenance of public order, and education for its induction into compliant citizenship. However, these views prevent sociologists from independently evaluating or comparing different moralities, if they are all assumed to be fairly equal and only understood within their own terms. The views assume that pre-social individuals (children) and noncompliant people are dysfunctional, immoral or amoral. Compliance is seen as the sole moral option when "actions are evil because they are socially prohibited, rather than socially prohibited because they are evil" (Bauman, 2003:173). Complete faith in the rulers who determine the norms ignores how rulers cannot guarantee virtue and may twist norms to serve corrupt interests. Contingent "moralities", which are produced and promoted within each society, deny the possibility of universal principles and therefore of universal human rights. They also undermine the value and importance of morality itself, because if moralities are interchangeable, their purpose and nature become questionable if not expendable.

The view that moral norms have to be enforced on inevitably antisocial young children implies that morality works against human nature. Bauman asks, however: If we are all born primitive savages where do societies' notions of goodness come from? How can we imagine or invent them if they are so alien to our nature? He contends that the universal morality is the courage to follow individual conscience, to defend and be willing to die for justice and solidarity. "For sociological theory, the very idea of pre-social grounds of moral behaviour augurs the necessity of a radical revision of traditional interpretation of the origins of the sources of moral norms and the obligatory power" (Bauman, 2003:177). Although he does not develop this point, 
Bauman raises possibilities to be considered later about innate morality in early "presocial" childhood.

Other dichotomies in sociology remain. Ageist mainstream research continues to ignore children and to address the "adult world" (formerly the world of "Man"), of which nevertheless children are an essential integral part. In tandem, most of the "new" childhood studies separately "begins, and to some extent ends, with the study of children and childhood" (James, 2010:215-6). But how does childhood end? In time, the age that ends childhood is varied and uncertain. In space, boundaries between childhood and adulthood are also fluctuating and porous, and virtually every part of society interacts with childhood.

When directly researching children's own views as social actors, researchers rely on the micro, interpretive approaches of strand 2, mainly separated from the larger concerns of strands 1, 3 and 4. Over-emphasis on contingent beliefs and behaviours, and on "childhood as a continually experienced and created social phenomenon" (James and Prout, 1997:245), can veer into cultural relativism, which risks rejecting universal structures, principles and rights. Lukes (2008) critiques relativism saying that seemingly equal respect for every culture ends by respecting nothing but tolerance, as if that is higher than justice and other principles. And tolerance is an oddly negative concept; we do not "tolerate" things we love and admire. Lukes argues that we can respect locally varied expressions of underlying universal principles.

A further problem is social constructionists' double standards when they state, for example, that "the researcher is not the knower of truth but rather the recorder and interpreter of multiple 'other' social subjectivities" (Beazley et al., 2009:369). Yet if there is no truth, how can that statement, as well as researchers' own texts, be more than "social subjectivities" without any essential, transferable meaning or relevance across place or time? Without some stable realities, how can we avoid infinite regress?

Turner's important validation of human rights partly shares strand 2's underlying dichotomies: thinking versus being; warning "not to reify 'the body"' (2008:245) as if bodies are not real; powerful but unreliable structures versus weak, anonymous agents; relative inattention to politics, economics and history; sociological theories with a Nazi-influenced past, but a supposedly value-free present. The dichotomies can inhibit attention to two matters essential to the study of the origins of human rights: real bodies and human agents interacting with political structures; and how and why rights have been so much ignored in sociology. Turner attributes his model of human vulnerability back to Nietzsche, via Arnold Gehlen who is "controversial", Turner says because he was a senior Nazi official and later a neoconservative - and also to Peter Berger who, despite spending his youth in Nazi Germany, celebrated powerful structures in his 1967 book, The Sacred Canopy. Gehlen (1988, quoted in Turner, 2008:9-11) considered that "Men" are "not yet finished animals" and survival depends on a long education, self-discipline, training and correction, and creating strong, stable, cultural institutions and habits, to give life coherence and meaning and relief from instinctual drives. Gehlen opposed all change as corrosive, and 
warned against the dangers of criticising institutions. If these points had been made during the 2011 "Arab spring", they would be expressed by the dictators rather than by protestors who were claiming their human rights. Turner (2008:10) notes that Gehlen's "work has been, somewhat paradoxically, important in the development of social constructionism", which assumes that because we cannot constantly reflect on countless everyday aspects of daily life, we subconsciously project a pragmatic, taken-for-granted, factual character on to the social world. To expose this illusion, Garfinkel conducted ethnographic "degradation" experiments, which Gouldner (1971:390-5) criticised as cruel.

Garfinkel illustrates that one danger in applying "value-free" standards from natural science to social science is inattention to ethics, as if research with and about people can be morally equivalent in its means and ends to research on particles. Value-free positivism can endorse moral indifference; interpretive research can lead to moral relativism; social constructionism can imply that bodies and suffering do not really exist or matter, and researchers who attempt neutrality and ignore conflict and discrepancies of power and interests are liable to support the powerful status quo (Gouldner, 1971; Bauman 2003; Freeman, 2011:117-8). The requirement that social science should be value free paradoxically makes a moral claim "should", not a factual claim that "social science is value free", since it frequently is not. So the edict breaks the rule that it is attempting to impose. Even Popper (1945/1965) hedged his implacable claims to objectivity in research within broader moral truth claims about freedom and opposing error and fraud.

Morality is so intrinsic to the human condition and relationships, that efforts to research the social world objectively, to separate empirical fact from moral value, cannot delete morality. Gouldner (1971) considers that these efforts simply remap and reorder the world towards other moralities of prudence or profit, utility or rulekeeping or, in Goffman's case, appearance. The usual human assumption is to equate power with goodness. When "value-free" utilitarianism frequently pronounces that things of power (such as finance) lack morality, and things of value (such as rights and justice) lack power, this is generally felt to be incongruous (Gouldner, $1971: 84 f)$. Older moralities arising from human nature, attachment, and shared need, the virtues of "kindness, courage, civility, loyalty, love, generosity and gratitude" have been replaced by calculating rational self-interest, which dismisses virtue as sentiment, "thinly disguises avarice", and resolves personal worth into exchange value (1971:75). Beyond treating children as commodities to be individually priced and labelled, the industrial scale of the research databanks treats them as nameless cohorts of risk probabilities (Dex and Joshi, 2005). To replace moral judgements with use judgements increases the hazards of anomie (Gouldner, 1971), and children are especially vulnerable, when adults make utilitarian decisions, if children's own views, reasoning and present wellbeing are discounted, and they are treated as "other" (not yet human beings or rights holders), as expendable means and future outcomes to serve adults' ends. If moral incentives are assumed to be rewards and punishments, but not personal motivation or commitment, then altruistic morality is tacitly seen as extrinsic and contradictory to selfish human nature. Gouldner (1971) considers that 
social research (influenced by strands 1 and 4) can serve to measure function, to justify allocating resources by merit rather than need, and to allay anxieties about exploitation and inequality, by lending the sanction of science to public policy. Hynes et al. (2011:826-77) identify a range of positions, from partisan or critically engaged and committed, to sceptical and even cynical, which all have a moral as well as an intellectual basis.

In strand 4, Popper's and Hayek's complex, professed ideals of freedom and the prevention of avoidable harm sit uneasily with the effects of their neoliberal policies in today's extremes of poverty, inequality, and punitive repression of the poor (Klein, 2007). The free movements they advocated of capital, trade and labour result in the mass migration of workers, reduction of wages and the fragmentation of families (Wacquant, 2009), powerfully affecting children and all their human rights. It is ironic that human rights, concerned with solidarity and equity (United Nations 1948, 1989), are frequently misunderstood and dismissed as the atomised, selfish individualism that neoliberals advocate. Neoliberals assume that managed structures weaken individual liberty whereas, paradoxically, the Arab protests illustrate how stronger democratic and legal structures can strengthen human agency and freedom. This is understood in interactive, dialectical theories of structure and agency, rather than within dichotomous ones.

The lawyer Conor Gearty (2011) sees human rights as "the ethical architecture necessary to decent everyday life" and "the only contemporary idea with true universal and progressive appeal...too important to leave to the liberals, the marketslaves or the neo-conservatives". Rights are one of the few present ethical resources we have, in the Western "post-socialist, post-religious haze of market supremacy", when rights respect everyone's dignity through structures of accountability to an independent rule of law, community self-government and, especially, equity. Gearty considers that rights connect wealthier Minority world countries to the energetic radicalism of the poorer Majority world and their claims to rights. Rights also connect to the best of the world's religions. The next section considers alternative approaches towards a sociology of rights that bridges dichotomies.

\section{Critical realism and human rights}

Bhaskar points to a deeper problem that inhibits sociology. If morality and rights are solely an epistemology, a social construction of malleable floating ideas, then their ontology, the real independent existence, say, of lethal abuse and deprivation, the realities of dehydrated children and safe water, are denied. If "there are only beliefs, knowledge, language, descriptions, you cannot refer to anything outside beliefs" or critically examine what they describe or attempt to capture. Further, you cannot think about "a discourse which will allow you to critically evaluate our current claims to knowledge...its ideological function" (Bhaskar, 2011:81-2). Critical realism offers means to surmount these problems. 


\section{Absence}

From the above model of disconnected, opposing sociological strands around a central void, this section considers ways to explore the void, and to identify and unite the strengths from each position. I will begin with a major concern of CR: absence. Recognition of absence helps us to address voids and splits in several ways. First, it moves beyond the single-value assumption that only the positive can be researched and allows us also to examine invisibility, omission and negativity (Bhaskar, 1998). The relative silence in sociology on children in the mainstream literature and on human rights can then become both a possible and indeed a crucial topic for analysis of what is missing. What are the likely causes (see previous sections) and remedies (this section) for the absences that explain and therefore underlie these contradictory dichotomies and dualisms? Second, it is realistic to recognise that absence, all the past and future, all potential alternatives to the present here-andnow, is infinitely larger and more powerful than presence. Bhaskar (2010) cites the monsoon that never arrives so that the crops perish. And there are the 2011 Arab protests about their violated rights and absent freedoms. Rights are at their highest value when they are disrespected and seem to be absent, because they are detailed, specific claims and tools for change, for imagining and achieving better futures and for absenting present oppressions. Third, recognising absence helps us to move beyond the fixed and static, beyond Gehlen's fear of corrosive change. This is because change involves absence, not just difference; every becoming involves a be-going and loss of a former state. Parents who respect their children's rights and growing competence have to accept the absenting and dwindling of their own authority and of their child's former dependence. Fourth, one way to begin to make sense of negative extremes, such as genocide, is to see them as absence of good, which informs the desire and drive towards the freedom that absents ills and constraints (Bhaskar, 2008:280).

\section{Ontology and epistemology}

A further common absence in sociology is certainty about whether things really exist or are more accurately treated as perceptions, constructions or discourses. Everyday common sense tells us all that things, from oceans, to beating hearts, to laws inscribed on stone or parchment, to kinship ties, really exist and we have to behave as if they do. Yet many sociologists doubt all existence, and worry about how we can rely on our own and other people's experiences, observations and accounts, or be certain that things continue to exist when they are not observed, or be sure that anything exists independently of how we perceive and construct it. These uncertainties influence childhood studies and the 'social construction of childhood'. At great length, CR analyses the long history and the flaws in these theories, and concludes that the world must exist independently of our knowledge of it. Bhaskar (1998) contends that researchers' defensive anxieties and inconclusive debates about reality displace their search for validation on to their theories (epistemology, relevance and coherence for interpretivists, see strand 2 and some of 3 ) or their methods (rigour, design and non-bias for empiricists and positivists strands 1 and 4). 
However, CR asserts, validity has also to be based in the original subjects/objects of research (humans and other species, things, events, structures, processes, ideas) and in how accurately they are understood. Researchers' over reliance on their own theories and methods is part of the epistemic fallacy. This reduces ontology into epistemology, things into (researchers') thoughts. We need to separate the independent, sheer, irreducible, intransitive being (ontology) of the things we research, from researchers' very different transitive knowing (epistemology). Sociologists who avoid the epistemic fallacy can combine positivist aspects of certainty of the existence of the intransitive objects and causal relationships being researched (strand 1 and 4), with interpretivist awareness of observers' transitive subjectivities (strand 2), a combination that respects parts of both traditions. So, for example, we can respect the reality of the written, ratified words in UNCRC, the world's millions of children, the privations they endure, and the remedies they need. We can also respect everyone's varying views on how the UNCRC might be defined, interpreted, researched and promoted.

\section{Depth realism, open and closed systems, structure and agency}

Rights have real ontology in several ways. Depth realism has three levels (Bhaskar, 2008). First there is empirical, sensed experience of rights, such as in the texts of Conventions and laws on human rights, and in the witnessing, reports and films of rights being violated or honoured. Universal rights have gradually been defined over centuries through repeated public protests against oppression and injustice, and have been refined and clarified through legal and philosophical debate. The UNCRC is almost universally agreed and ratified, and it can have real political and practical effects when people work to implement it in the courts and in public life and policy. Even if the 1998 Human Rights Act were to be repealed by its opponents, the precedence of many court cases since 2000, based on the Act, ensure its lasting existence and influence in English common law.

The second level combines the empirical with actual events, in which rights are central. For example, the Arab protests occurred in the most water stressed countries on earth (Carrington, 2011). Long-term drought, wells that are emptying the centuries-old deep aquifers, water pollution, the rising cost of oil to fire desalination plants, and the privatisation and costly sale of water, all threaten the human right to safe drinking water (UNCRC, 1989, Article 24,2c). This right exemplifies how all rights are interrelated, and inhere in human bodies. The right to clean water relates to rights to life, food, and an adequate standard of living, as well as to the services, infrastructure, and political economy necessary to support rights to utilities, healthcare, and education, which enable freedom of information and expression, and a life of human dignity and fulfilment from birth (United Nations, 1989). All these rights are expressed and exercised, honoured, ignored or violated through bodies, and also through how bodies are respected and nurtured, or deprived, confined, tortured or enslaved. Rights to freedom of thought, conscience and religion (United Nations, 1989:14) affect babies, for example, through respect for their family's right to worship, to free association, and to attend the welcoming 
ceremonies that many religious communities hold for their newborn members, without fear of discrimination or persecution (Alderson, 2008).

Most social research remains at the vital but limited two levels of the empirical and actual (Bhaskar, 1998), which trace associations between observed things, events and effects. The equivalent in physics would be to record numerous falling objects, and to search misleadingly within them and their constant conjunctions for the cause of the falling. However, causal powers and explanations lie at the deeper third level, which combines the empirical, the actual and the real. Natural and social objects and structures are real in having causal powers that can generate real events.

Gravity and evolution are examples of causes, which cannot be seen or proved in themselves, only in their effects, as in falling objects for gravity, or finches' beaks that change over generations for evolution. We readily accept invisible not directly provable causes in the natural sciences. Bhaskar (1998) argues that invisible causes in the social sciences are equally valid: inequality, class, 'race', gender, and adultchild relations. In social research, to follow Newton or Darwin we would stop trying to trace and measure innumerable empirical (observable) correlations between data in the birth cohorts, such as personal connections between children whose parents encourage early language, and those who later do well at school (Feinstein, 2003). That is like trying to find causal patterns and associations between falling objects. Instead like natural scientists looking for the deeper cause and consistent explanation of gravity, social researchers would consider class and inequality as underlying real causal, political explanations.

A common argument against identifying poverty and class as reliable causes is that some very disadvantaged children succeed well, and some privileged children fail badly. Therefore, conclude the critics, class is not a definite or strong influence, whereas personal motivation is. CR responds with the concepts of closed and open systems (Bhaskar, 1998). First, there are very few closed systems that have inevitable, 100 per cent effects. Water does not boil everywhere at $100^{\circ} \mathrm{C}$; cancer drug controlled trials produce a range of outcomes and survival rates. Second, a single isolated system is also very rare: air currents and aerodynamics can work against gravity; in society, innumerable known and unknown influences interact and affect people. Third, social systems are open because they involve unpredictable, thinking, choosing, reacting people, not predictable molecules in a test tube. However, CR still considers that deep causes such as class, despite their varying albeit majority effects, are powerful and crucial. We should avoid the double standard of accepting unseen powers such as gravity in physics, but rejecting unseen powers such as class in sociology.

In sociological debates about structure and agency either strong structures dominate weak agents or (mainly in strand 2) strong agents select and produce structures and "construct childhoods". CR distinguishes between conscious, intentional agents and the non-living structures they inhabit; structures powerfully enable but also constrain agents. As agents we cannot "construct" children, or childhood which is an ancient historical, biological and social kinship structure we all unavoidably inherit. We can, however, keep reconstructing and transforming our 
local beliefs and behaviours about childhood. Bhaskar and Marx also examine how agents' efforts to alter structures are likely to be unintended, inadvertent and unsuccessful in the constant dialectic between structure and agency. Social structures cannot exist without human agency; agents cannot exist without social structures of language, kinship and learning. But neither of these can be reduced into or confused with the other. They are interdependent but different. Human rights involve real and aspirational structures of justice, freedom and equity, besides human agents, who claim, respect, negotiate or deny rights, refine and implement them. The next section considers the long history of the emerging structure of human rights.

\section{Four planar social being}

A major division in sociology, reviewed earlier, is between large-scale, impersonal cohort and structural research (strands 1 and 4), and small-scale, personal studies (strand 2). CR offers ways to combine these approaches into more holistic and coherent analysis of rights, through the four interacting planes of social being (Bhaskar, 2008:153).

Plane I concerns physical bodies in the natural world. In the earlier example of water, the ontology of all interrelated rights resonates with the ontology and flourishing of both human nature and the global ecology in which it survives. If rights are inalienable, and therefore universal, they relate to the universal nature and needs of human beings as rights holders. The Kantian view, that only rational "Man" has rights, falls into the epistemic fallacy, because it largely defines rights as matters understood and exercised through the intellect. It ignores how bodies are also involved, and excludes most human beings, especially the most vulnerable, for whom rights-claims are often most necessary. The gradual inclusion over history of all adult groups as rights holders, however disabled they may be, increases the case for including young, "pre-social" children.

Yet philosophers' visions of "pre-social" children, with blank pages or buzzing confusion for minds, have been refuted by psychological research on baby's highly social responses: their sensitive awareness and communication; their intense curiosity and predisposition from the start to find meaning and patterns in what they see, hear and feel; their "autonomy" in firmly expressed views, protests and smiles (Murray and Andrews, 2000). Even premature babies have a "language", that adults can "read". They remember, from before birth, their parents' voices, which they prefer to other voices (Als, 1999; Alderson et al., 2005).There is also babies' concern for others (Stern, 1977), which soon finds expression in a rudimentary sense of sympathy-solidarity and fairness-justice, in their conflict and resistance, being "good" and "naughty" (Dunn, 2004), all responses connected with rights. Babies' essentially social and not simply egotistical nature is shown in how they use other people's names for months before saying their own name.

One related question is when does each human spirit or unique identity first emerge? Martin and Barresi (2006) review how, over millennia, concepts of an immortal and possibly sacred soul have gradually fragmented into the contemporary 
Goffmanesque performing persona. They cite how Plato and others could only account for the human intellect by believing in its prenatal existence because children's mathematical and philosophical powers seem to precede and exceed their education. The mysterious, unique person that many parents sense within each new baby cannot wholly be explained by genetics (Midgley, 2010).

Plane 2 of social being, interpersonal subjective relationships between individuals and groups, expands on the social aspects of human nature. Modern rights might encode very recent versions and norms of human relationships that have origins in prehistoric human communities, as well as in seemingly innate human dispositions. Both these historical and psychological beginnings would suggest that rights are integral to human nature and relationships, rather than being superficial, expendable ideas. This is not to say that, much before the twentieth century, people held conscious concepts of modern, equal, international rights, any more than of Freudian analysis. However, ideas relating to rights (and to psychoanalysis) were debated in classical Greek and Hindu drama and poetry, and respect and freedoms seem always to have been accorded at least to certain groups such as kings and priests, in master-slave relationships (Bhaskar, 2008). Intuitive recognition, with acceptance or negotiation of hierarchies, dominance and subservience, honour or contempt, may be inextricable elements of human interactions. Rights are then a device to increase the groups deemed to deserve respect "for their worth and dignity", from aristocrats in the past to everyone today.

The philosopher Mary Midgley (2010) draws on Darwin's theories of early human relationships, not in terms of unchanging, stone-age, human biology, but in seeing humans as social animals with much in common with complex pack, herd and flock species, with their "pecking order". This approach argues that we do not have language and reason because we are clever, but because we are intensely sociable. We are innately predisposed to relate, share and communicate like other animals, and additionally we reflect self-consciously and imaginatively, and feel guilt and regret, shame and pride. These activities and emotions relate tacitly or overtly to shared respect for everyone's rights.

Within personal relationships, babies' rights to basic provisions and protections to enable them to survive are generally supported. The contested children's rights tend to be the freedom and autonomy rights, with concern that these might allow children to harm themselves and others. However, this opposition stems from centuries of prejudice that children and young people - and women - are ignorant, emotional, irrational and unreliable. These stereotypes have been dispelled for women, and are being increasingly challenged by researchers and other adults who work and care for young children (reviewed in Mayall, 2002; Alderson, 2008). Human nature at all ages combines strong and weak qualities, and human rights are not denied to foolish adults.

Plane 3 of social being involves broader social relations and inherited structures, which suggest that, explicitly recognised or not, experiences relating to rights are woven into human history. Woodiwiss (2005) traced modern inalienable rights and respect for human dignity back to ancient, formal religious rites and beliefs in the 
soul, and in God-given respect for the sacred in human nature. Nisbet (1967:221263) considered that sociology is the only social science to examine how religiosacred myth, ritual, and sacrament inform secular life, and to perceive human nature and society as intrinsically moral, instead of assuming that secular, economic, utilitarian, self-interested, and competitive doctrines are "the essential and sufficing pillars of social analysis" (1967:221). Nisbet reviewed classical sociologists' contentions that religions implant a deep sense of unity and meaning, social order and duty, the sacred bonds of the social contract, together with respect for individuality and true human nature, wisdom and virtue, which are safeguards from paralysing fear, disorder, and tyranny. They anticipate Gearty's view of modern rights cited earlier.

Whether they take a Hobbsian view of the war of all against all that can only be controlled by the state, or Rousseau's romantic ideal of the unspoiled child of nature, the idea of primitive barbarity or a former idyllic golden age, these versions of prehistory share three themes that relate to human nature and rights: human identity (plane 1), social relationships (plane 2) and organised society (plane 3). Rights are especially important in the third theme, as they primarily concern states' duties to protect and provide for the citizens and also to respect their freedoms. This involves managing diverse groups and conflict, besides promoting the human energy, curiosity and initiative that benefit the whole society.

However, the historian, Christopher Goodey (2011), has traced a common theme across societies, which challenges equal rights, when an upper stratum has long been distinguished: in terms of honour in classical times, merging much later into notions of the Christian elect versus the reprobate, and transforming into modern meritocratic concepts of the intelligent versus the intellectually disabled. This partly explains the continuing paternalism that restricts recognition of children's rights (Goodey, 2011:327-9).

Plane 4 in the stratified, embodied human personality concerns personal freedom of conscience and agency, working towards the flourishing good life for all in the good society. Often dismissed as vaguely Utopian, the good society has detailed, agreed maps of the society and the routes towards it enshrined in human rights. There is not space here to discuss this complex plane and further ideas from $\mathrm{CR}$ about the momentum and direction of social agency and change (Alderson, in press).

\section{Conclusion}

This paper has considered possible reasons for sociology's relative silence on rights and on the Holocaust as a catalyst, explanation and validation of international human rights. The paper has also considered the literal meaning of inalienable human rights for everyone from birth, and possible obstacles to developing a sociology of rights. These include dichotomies - adult/child, social/pre-social, culture/nature, mind/body, personal/political, value-free/bias, structure/agency, universal/contingent, 
empirical/interpretive, micro/macro - which can divert sociologists into presenting one-sided, half-way and misleading accounts, and can also deter analysis of complex entities such as human rights and childhood, which transcend the dichotomies. Babies as rights-holders raise questions about nature and culture, innate and learned capacities, and the meaning of human worth and dignity, which involve thinking beyond the bounds of sociology, across the humanities and the social and natural sciences.

Present dichotomies and boundaries may partly be attributed to sociologists' efforts to control chaotic everyday life, and divide it into manageable portions for social analysis. There may also be aversion to confronting real mayhem and suffering, such as wars and genocides, which painfully challenge sociologists' confidence to make sense of dangerous and unjust societies. It is as if many sociologists have withdrawn from a largely unacknowledged chaos or absence at the heart of society and of sociology, into opposing directions: towards functionalist denial of injustice, or retreat from the political into the personal, towards rejection of reality and therefore of real physical suffering, or into defence against fascism through neo-liberalism. These responses all sideline human rights. They also challenge sociology's coherence and internal and public credibility by locking sociologists into contradictory positions between the extremes of positivist faith in a pristine, stable, transferable, factual reality versus interpretive attention to personal perceptions and constructions of contingent, transient interactions (Bhaskar, 1989, 2008; Scott, 2010).

CR offers approaches that address the gaps, bridge dichotomies, and close contradictions, towards strengthening theory and research on human rights. The approaches include exploring absence, four planar social being that unites human nature and relationships, agency, structures and flourishing, besides distinguishing transitive epistemology from intransitive ontology, and recognising the reality of textual, legal, political, interactional, embodied and causal human rights. Broad, universal, intransitive principles in UN rights treaties are open to transitive local negotiation and application, to which sociologists could vitally contribute (Freeman, 2011 ) to help to reverse the present great shifts of resources and power away from younger and towards to older generations. Rather than belittling human rights, future research about younger generations may increase interdisciplinary understanding of the political and embodied nature and purpose of inalienable human rights.

\section{References}

Alderson, P., Young Children's Rights (London: Jessica Kingsley, 2008).

Alderson, P., Childhoods Real and Imagined: An Introduction to Dialectical Critical

Realism and Childhood Studies (London: Routledge, in press).

Alderson, P., Hawthorne, J., Killen, M., "The Participation Rights of Premature

Babies", International Journal of Children's Rights 2005 (3)31-50. 
Alderson, P. and Morrow, V. The Ethics of Research with Children and Young People. (London: Sage, 2011).

Als, H., "Reading the Premature Infant", in E. Goldson (ed.), Developmental Interventions in the Neonatal Intensive Care Nursery (New York: Oxford University Press, 1999).

Bauman, Z., Modernity and the Holocaust (Cambridge: Polity, 2005).

Beazley, H., Bessell, S., Ennew, E., Waterson, R., "The Right to be Properly Researched: Research with Children in a Real Messy World", Children's Geographies 2009 (7(4)), 365-78).

Berger, P. and Kellner, H., Sociology Reinterpreted: An Essay on Method and Vocation (Harmondsworth: Penguin, 1981).

Bhaskar, R., The Possibility of Naturalism (London: Routledge, 1998).

Bhaskar, R., Dialectic: The Pulse of Freedom (Abingdon: Routledge, 2008).

Bhaskar, R., Philosophy and the Idea of Freedom (Abingdon: Routledge, 2010).

Bottomore, T. (2002) The Frankfurt School and its Critics. London: Routledge.

Bhaskar, R., From Science to Emancipation: Alienation and Enlightenment (Abingdon: Routledge, 2011).

Carrington, D., "Vanishing Lifeline”, Weekly Guardian 2011 (185(4)),:25-7.

Chalmers, I., "Bill Silverman: A Personal Appreciation", Paediatric and Perinatal Epidemiology 2005 (19(2))82-5.

Dex, S. and Joshi, H., Children of the $21^{\text {st }}$ Century: From birth to nine months. (Bristol: Policy, 2005).

Dunn, J., Children's Friendships: The Beginnings of Intimacy (Oxford: Blackwell, 2004).

Durkheim, E., Education and Sociology (Glencoe: Free Press, 1956).

ESRC - Economic and Social Research Council, Research Ethics Framework (Swindon; ESRC, 2005).

European Council. European Convention of Human Rights (EC, 1950).

Feinstein, L. "How can we predict future education achievement?" LSE CentrePiece, Summer 2003:24-30.

Freeman, M., Human Rights (Cambridge: Polity, 2011).

Freeman, M. D. A., "Why it remains important to take children's rights seriously", International Journal of Children's Rights 2007 (15(1),5-23.

Freeman, M. D. A., "Introduction", Law and Childhood Studies (Oxford: Oxford University Press, 2012)

Gearty, C., retrieved December 7, 2011 from http://therightsfuture.com/about/ (2011).

Gehlen. A., Man, His Nature And Place in the World (New York, 1988).

Goffman, E., The Presentation of the Self in Everyday Life. (Harmondsworth:

Pelican, 1969).

Goodey, C., A History of Intelligence and "Intellectual Disability": The Shaping of Psychology in Early Modern Europe (Farnham: Ashgate, 2011).

Gouldner, A., The Coming Crisis of Western Sociology (London: Heinemann, 1971). 
Hale, B., "What Future for Children's Rights in England?", Annual Meeting of the Children's Rights Alliance for England (London, December 2011).

Hynes, P., Lamb, M., Short, D., Waites, M. "Sociology and human rights:

confrontations, evasions and new engagements", The International Journal of Human Rights 2011 (14(6))811-32.

Invernizzi, A., "Everyday lives of working children", in A. Invernizzi and J. Williams (eds.) Children and Citizenship (London: Sage, 2008).

James, A., "Interdisciplinarity - for better or worse", Children's Geographies, 2010 (8(2))215-216.

James, A. and Prout, A. (eds.) Constructing and Reconstructing Childhood (Abingdon: Routledge, 1997).

Klein, N., The Shock Doctrine (London: Penguin, 2007).

Layard, R., Happiness: Lessons from a New Science (London: Penguin, 2006).

Lukes, S., Moral Relativism (London: Profile Books, 2008).

Martin, R. and Barresi, J., The Rise and Fall of the Soul and Self (New York:

Columbia University Press, 2006).

Mayall, B., Towards a Sociology for Childhood (Buckingham: Open University, 2002).

Midgley, M., The Solitary Self: Darwin and The Selfish Gene (Durham: Acumen, 2010).

Mirowski, P. and Plehwe, D. (eds.) The Road from Mont Pelerin: The Making of the Neoliberal Thought Collective (Cambridge MA: Harvard University Press, 2009). Murray, L. and Andrews, H., The Social Baby (Richmond: The Children's Project, 2000).

Nisbet, R., The Sociological Tradition (London: Heinemann, 1967).

Parsons, T., The Social System (New York: Free Press, 1951).

Popper, K., The Open Society and its Enemies, Preface to $2^{\text {nd }}$ edition (London: Routledge \& Kegan Paul, 1945/1965).

Scott, D., Education, Epistemology and Critical Realism (London: Routledge, 2010).

Stern, D., The First Relationship: Infant and Mother (Glasgow: Fontana, 1977)

Turner, B., The Body and Society (London: Sage, 2008).

United Nations. UDHR - Universal Declaration of Human Rights (New York; UN, 1948).

United Nations. UNCRC - Convention on the Rights of the Child (New York: UN, 1989).

Wacquant, L., Punishing the Poor (London: Duke University Press, 2009).

Weber, M., From Max Weber, trans. Gerth, H. and Mills, C. Wright (London:

Routledge \& Kegan Paul, 1970).

Woodiwiss, A., Human Rights (London: Routledge, 2005). 